\title{
Icelandic newsrooms in a pandemic mode
}

\author{
Birgir Guðmundsson, Associate Professor, University of Akureyri
}

\begin{abstract}
Covid 19 has had enormous impact on media firms all over the world, adding further economic pressures to a sector already suffering problems. Two different trends come together in the present situation, a challenge to the economic model of traditional media and a massive move to remote or working from home practices by journalists and editorial staff. This, in conjunction with other changes in the media environment, has raised questions about traditional institutions of journalism and journalist practices such as the physical newsroom. Speculation about virtual newsrooms or remote journalism practices and a wave of newsroom closures or downsizing due to Covid 19 in the summer and fall of 2020 has highlighted these concerns even further. In this context the paper looks systematically at the response of Icelandic newsrooms to the ban on gatherings that was introduced in the first wave of Covid 19 in the spring of 2020. The practical measures taken by the newsrooms are looked at, the experience of journalists recorded, and the content output measured, analysed, and compared to the same period the year before. Results show that work processes were radically changed, journalists showed flexibility and are relatively open towards permanent changes based on their experience of working from home. There is an impact on content output, but it is in most cases marginal.
\end{abstract}

Keywords: Newsrooms; journalist working practices; work from home; Covid 19; Icelandic media.

\section{Introduction}

The ban on gatherings that was imposed in Iceland on the $16^{\text {th }}$ of March 2020 and lasted until early May, throughout the first wave of the Covid 19, had great impact on the newsrooms of the media. The Icelandic media shared an experience with most media in the world as the pandemic called for similar reactions everywhere. In what follows

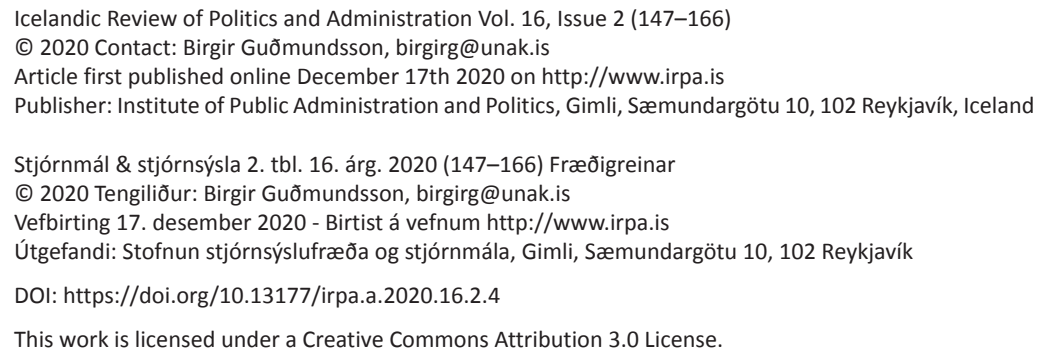


a systematic attempt will be made to examine how and to what extent the protective health safety measures had on journalistic practices. Limits on the number of persons in a locale and social distancing led amongst other things to extensive remote working in Iceland as was also the case elsewhere with the result that important questions were raised about journalism and some of its traditional institutions. Little research has been conducted on this important topic and none on the impact of Covid 19 on working practices within the Icelandic media. This paper is thus the first, empirical research to be conducted on the matter. The pandemic spread to Iceland in the middle of March 2020 and the first wave resulted in an extensive ban on gatherings, which lasted until early May. A small second wave surfaced in the late summer and then in October a third wave hit the country, resulting in further restrictions on gatherings. Clearly, as such a short time has elapsed since the outbreak of the pandemic it can be difficult to evaluate the experience of the unprecedented situation it has created. Yet, certain aspects and lessons have been emerging, mostly from the first wave, aspects that will be approached by looking at how media organisations dealt with restrictions imposed on newsrooms, what the experience of journalists was working under these new conditions and what the editorial output looked like in comparison with the year before. It should be noted from the very outset, that the research this paper is primarily based on was focused on the first wave of the pandemic, but as the pandemic continues new additional perspectives may emerge.

\section{Media market developments}

Changes in newsrooms have been discussed for many decades, both in scholarly literature and within the media industry itself as the practice of journalism has been evaluated and re-evaluated in ever changing societies. This discussion has been magnified with the digitalization of media, the advent of new technologies and an ever-increasing array of communication platforms available to the public and journalists. However, it has been noted that journalists have a conservative mindset when it comes to change (Boczkowski 2004). Ryfe (2012) suggested that American newsrooms were largely characterized by a "yes, but" syndrome when it came to innovation and change. This syndrome has also been noted by others when it comes to the introduction of online journalism and innovation in the newsroom (e.g. Paulussen 2016). Ryfe pointed out through an ethnographic research into American newsrooms in his celebrated book "Can Journalism Survive" (2012), that the "yes, but" syndrome in American newsrooms could be explained in terms of three main elements, i.e. habits, definitions and investment. Habits are important in the journalistic routine and can be difficult to stop, the very definition and purpose of journalism is deeply rooted in tradition and to invest in new practices requires costs that journalists tend to see as outweighing the benefits. Yet in recent years there have been changes in newsrooms all over the world. Unions and missions related to "professional and/or ethical journalism" have pointed out that fast developing technology and commercialization has transformed the working conditions of journalists, increased their work load and challenged them to follow and adopt new platforms, while consumer preferences measured by market researchers deny them the possibility 
to report on issues in depth, but opting instead for quantity and tabloidization (White 2009). These megatrends of commercialization and technological change have changed the media environment as the economic models of traditional media have weakened and instrumentalist pressures on journalists increased. Organizational professionalism has become more visible and important making for a continuous negotiation with the more traditional occupational professionalism of day to day journalism (Evetts 2011; Örnebring 2009). The feeble economic situation of traditional news media is underlined in the European Commission's Media Pluralism Monitor 2020 where seven European countries are recorded as high risk for media viability as the capacity of the large social media companies for targeted advertising have "shifted revenue away from traditional news publishers” (Media Pluralism Monitor 2020).

New network media logics have mixed with traditional media logic creating hybrid media systems that display different characteristics from older more traditional systems (Klinger \& Svenson 2014; Chadwick 2013; Chadwick et al. 2016). This in turn raises important questions about the centrality of the newsroom as an institution and the centrality of journalists in news reporting in general. The creation of news in modern hybrid media systems is a multifaceted process with a broad range of actors - in addition to journalists - involved in the process. Furthermore, the creation of news is not anymore confined to the newsroom as a physical locale but dispersed in networks and geographical locations. Indeed, traditional journalism's alleged reluctancy towards innovation, is being challenged by the ever-increasing change in the media ecology where journalists remain an important focus of news making, but are not the only one (Boczkowski 2015).

The megatrends of commercialization and technological change have characterized the development of media and journalism in Iceland in the first two decades of the $21^{\text {st }}$ century. The Icelandic media system has been shown to possess the important qualities of a hybrid system with old and new media logics simultaneously at work (Guðmundsson 2019). However, the small size of the Icelandic media market has intensified the impact of the megatrends and made the country even more sensitive to them than is the case in larger societies (Guðmundsson 2018; Jóhannsdóttir \& Ólafsson 2018). Icelandic media was hit hard by the financial crisis of 2008 and although media companies faced some financial difficulties before the crisis, difficulties have been felt even more acutely ever since. After the crisis, many journalists lost their jobs, and the volume of media output shrank considerably (Jóhannsdóttir 2016; Guðmundsson 2011). One indicator of the heavy impacts is the number of members of the Journalist union of Iceland. Although a high number of journalists retained their membership after layoffs, the number of members shrank from 638 in 2007 to 566 in 2012 and there were only 569 members in April 2020, considerably lower than in 2007 (Blaðamaðurinn 2007, 2012, 2020). The Icelandic media market is thus economically vulnerable and ownership transitions, mergers and volatility has been particularly evident (Jóhannsdóttir \& Ólafsson 2018). The annual balance sheets for example for 2018 of most media companies in Iceland reported losses and even though departments in some of the companies showed profit that did not change the general picture (Björnsson 2019). 


\section{STJÓRNSÝSLA}

\section{Newsroom innovation}

Whether journalists as a professional group have been reluctant or not when it comes to changes in the newsroom, it remains true that journalists and newsrooms are still one of the most important pillars of modern news reporting. In fact, the discussion of new communication technologies and possibilities in news reporting, has been ongoing and closely related to the issues of professionalism and the economic necessities of media companies described above (Guðmundsson \& Kristinsson 2017).

One such area of discussion is remote working and virtual editorial offices. These have become a part of the discussion of quality in journalism as journalists in different places can, through various platforms, pull their resources and co-operate in crossborder investigative journalism (Lanosga et al. 2019). This has been linked to the development of Online Collaborative Software (OCS) or even of particular platforms or editorial systems such as Slack (Bunce et al. 2018). There is some evidence that through these platforms, journalists can overcome geographical distances and establish meaningful journalistic cooperation (Konow-Lund 2020). Furthermore, innovation in the newsroom has taken place in online journalism and the way in which these new platforms are integrated into editorial practices (Paulussen 2016). Lastly, but what is perhaps most relevant to the present topic, is the closure of newsrooms and merger into larger ones as centralization and rationalization move higher up the agenda of the media industry. The option of remote working has for example had negative effects on local newsrooms as they are taken over by larger ones and the locality is covered first by small "outposts" and then sometimes by a single reporter (Nygren 2019). There are also positive aspects to this development, as these takeovers and mergers are first and foremost of an economic nature. With dwindling advertising revenues and fewer subscriptions, the economics barely sustain many of the media firms while mergers and rationalization help keep others in operation. In addition to an already difficult general economic environment for media, the Covid 19 pandemic has worsened the situation considerably. Statistics on the measures of downsizing and/or cutbacks that are directly connected to the outbreak of the Covid 19 pandemic in different countries of the world are not easily accessible, but The Tow Center for Digital Journalism has been collecting data on US newsroom cutbacks that occurred during the COVID 19 pandemic. They call it the "Tow Center COVID 19 Newsroom Cutback Tracker" and this database has recorded hundreds of different cutback measures at media firms in the US, ranging from layoffs and pay-cuts to mergers and closures. According to this database between $9^{\text {th }}$ of July and $9^{\text {th }}$ of November 2020 there were 46 closures of media outlets, mainly newspapers. At the same time there were additionally 7 office closures and 19 mergers of companies and hundreds of other measures (Tow Center 2020).

The Covid 19 effects on news organizations is a subject of public discussion as is demonstrated in an analysis in the Washington Post in the summer of 2020 (Izadi 2020). The analysis reported a wave of newsroom closures in the US as the pandemic has simultaneously created major economic problems for media firms and forced journ- 
alists to work from home suggesting that it is possible to produce quality journalism via remote working. Closing physical newsrooms or downsizing them considerably and relying more extensively on "virtual newsroom" features is an option already being utilised by a number of companies. It should be noted that in some cases, remote working can be beneficial for the journalism practiced. As Ann Marie Lipinski, curator of the Nieman Foundation at Harvard University and former editor of the Chicago Tribune noted: "There are areas of journalism that can actually be improved by letting people work where they live as opposed to live where they work" (Izadi 2020). However, according to the Tow Center Cutback Tracker and the Washington Post the motives behind management decisions to close newsrooms are not journalistic. The motives are financial. Many of these established newsrooms occupy valuable real estate, that can be, and have been, sold or leased. The Covid 19 pandemic has thus taken questions of newsroom innovation and change to a new level, where the discussion revolves, around the very existence of a physical newsroom, and what role, if any, it plays in the complex contemporary hybrid media system. The realities forced upon the media systems of the world and the institution of the newsroom by Covid 19 are unprecedented and their impact is already being felt. However, little time has elapsed since the pandemic hit the world and therefore limited systematic research is available. Below an attempt is made to map out some of the reactions and changes in media and newsroom practices that have followed the ban on gatherings imposed to control the pandemic in Iceland. This was done through posing three main research questions.

Firstly, the way in which major media outlets coped with the regulations imposed by health authorities between $16^{\text {th }}$ March and the $4^{\text {th }}$ of May 2020 have not been systematically mapped out. Nor has it been examined whether editorial work processes, internal communications, editorial meetings, and important elements associated with the newsroom continued to function while editorial offices were in a "pandemic-mode". Hence the first question was:

\section{RQ 1. How did the large national media companies maintain their internal work processes during the ban on gatherings between $16^{\text {th }}$ of March and $4^{\text {th }}$ of May?}

In light of the discussion above, on the "yes, but" syndrome of journalists when it comes to change, the question arises how Icelandic journalists reacted to the changes that inevitably had to be made in working practices. Communication formats clearly had to change and go online, and it is important to determine whether editorial independence, work style and selection of sources were affected. Therefore the second research question posed was:

RQ 2. How did journalists experience their possibilities and conditions to create editorial content during the ban on gatherings between the $16^{\text {th }}$ of March and the $4^{\text {th }}$ of May? 
Lastly, the outcome of the editorial process is clearly of vital importance. Is there a marked difference between the news production of the media during the ban on gatherings and the news production the year before, when there were no restrictions and the situation in the newsrooms was "normal"? A question which leads to the third and final research question:

RQ3. Is there a difference in the newsroom output when there was a ban on gatherings from $16^{\text {th }}$ of March until $4^{\text {th }}$ of May 2020 and when there were no restrictions in the same period in 2019 ?

By addressing these three questions an attempt is made to map out some basic information about the impacts of Covid 19 on the media and newsroom practices.

\section{Methods and measurements}

To answer the three research questions three different methods were used to gather data. For the first question information was sought through personal exchange with the heads or deputy heads of editorial offices. For the second question a survey was conducted amongst operating journalists and for the third question content analysis for some of the major news outlets was conducted.

Regarding RQ1 information was collected from editors, news editors or deputy news editors of four of the main national news outlets. These were: Heiðar Sigurfinnsson, deputy news editor at the RÚV newsroom (state broadcasting service tv and radio); Pórir Guðmundsson, chief news editor at Sýn, the joint newsroom of Stöð2 (tv), Bylgjan (radio) and Visir.is (website); Jón Pórisson editor in chief of Fréttablaðið (daily newspaper, free) and Guðmundur Hermannsson, news editor at Morgunblaðið (daily newspaper, subscription). An interview guide was constructed, and the editorial chiefs were all presented with the following issue agenda regarding the operation of their newsrooms (Matthews \& Ross 2010):

- What proportion of the editorial staff (and technicians) conducted work remotely and what technical platforms were used by journalists, editors and layout/technical people to communicate?

- Were editorial meetings with journalists held in a different manner and did they have the same role as before? Was there more reliance on person to person conversations rather than group conversations (e.g. directly between an editor and a journalist)?

- Was it possible to maintain an adequate flow in the production processes so that internal deadlines and final deadlines could be met?

- Was there anything that came as a surprise or was unexpected related to the change in working conditions and practices? 
As is demonstrated by the openness of the last point, in some cases additional information and experiences were provided. The exchange with the editorial chiefs was both through e-mail and telephone in August 2020.

RQ2 is focused on the experience of journalists. A descriptive comparative study in the form of a web survey was conducted among journalists actively working in operating media in Iceland. A list of addresses was gathered from the websites of different media platforms and by direct correspondence with editorial offices. The sample of respondents selected, constituted more or less the complete population to be studied (Fowler 2014), and represents fairly the diversity of media outlets. However, the gender ratio of active journalists was not balanced with $60 \%$ males and $40 \%$ females. About 260 survey-links were sent to the target population of operating journalists both those working in news and those working in other areas of journalism. Some 16 e-mail addresses were invalid or temporarily disconnected. Thus 244 journalists, practically all active journalists in Iceland (not all members of the Journalist Union are actively working as journalists), received the survey, 148 responded or just over $60 \%$. The survey consisted of 8 multiple-choice questions, presented in a closed question format to facilitate reliability of both responses and interpretation (Fowler 2014). The main questions asked: if the journalists had experienced remote working, how they liked it, if they found it easy or difficult to do their work remotely, if the equipment they had was adequate, and finally whether or not they would be prepared to take up remote working to a greater extent than before. The survey was conducted through the software SurveyMonkey, in early September and was open for two weeks with one reminder sent out.

RQ3 focused on content analysis on some of the major news outlets. Two daily newspapers and the two main broadcasting platforms were selected for analysis. The ban on gatherings during the first wave of the pandemic lasted for 7 weeks and for a credible sample of the output during this time, three weeks were chosen for analysis, one in the beginning, in the middle of the period and towards the end (Bryman 2012). The newspapers were analysed as a whole, and different sections and content types labelled, with the space allocated to each content type measured. In the case of the broadcasting outlets, the main news hours of two tv stations and the two radio stations were analysed. No online news production was measured, as this was beyond the research capabilities at hand. (That decision was reaffirmed by responses from the editorial chiefs who all noted that of the different media platforms the restrictions had the least impact on websites.) The newspapers were analysed in their entirety in 21 categories and subcategories, based on a coding manual developed in view of the research questions (Bryman 2012). The broadcast news hours were coded into 12 categories and subcategories. However, for the purpose of this paper and the scope of analysis, some of these categories have been merged, and as a result five categories form the basis of this analysis: hard news (politics, economics, judicial matters etc.); soft news (mainly human interest); "raw" press releases; press releases and an identified source; an edited news item with one or more independent identified sources. The assumption is that the more independent sources a story is based on, the more journalistic work it is required. These categories were select- 


\section{STJÓRNSÝSLA}

ed to provide a picture of the type and nature of reporting conducted by the newsrooms during the periods in question. In addition to these five categories the amount of news and advertising in the newspapers was also recorded including their total size and in case of the $\mathrm{tv}$ and radio the total length of news broadcasts.

\section{Results}

First the outcome of the personal exchanges with editorial chiefs on the measures adopted in response to the ban on gatherings will be presented, followed by a discussion of the findings of the survey among practicing journalists. Finally, the outcomes of the content analysis will be introduced before the implications of the findings will be discussed in the concluding chapter of the paper.

\subsection{Practical measures in response to the ban of gatherings}

The ban on gatherings was introduced on the $16^{\text {th }}$ of March and lasted until the $4^{\text {th }}$ of May. However, the ban had been expected and took a milder form in the first week, so the editorial offices of the four biggest news media had some time to prepare. The restrictions included a social distancing ban of a mandatory 2 meters and a 100 person limit on gatherings, which by week 2 was reduced to 20 persons.

According to the editorial chiefs at Sýn, RÚV, Fréttablaðið and Morgunblaðið, similar measures were taken by both the newspapers and by the broadcast media. Four points will be considered here: the extent of remote work; communication; workflow and deadlines; social interaction/isolation.

\section{Extent of remote work}

At the broadcast media the $\mathrm{tv}$ news studios remained open and staff, reporters and technicians, were divided into two separate shifts that did not interact. At RÚV and Sýn, about half of the reporters worked from home at any given time, at Sýn the same group worked mostly from home all the time, while at RÚV half of the reporters on duty at any time worked from home. However, some types of reporting were mostly conducted from the journalists' homes, for example for radio and websites. It seems that reporters were quick to adjust and Dórir Guðmundsson from Sýn for example points out that reporters reporting for radio would read in stories on their telephones or find other ways to record with reasonable sound quality.

With respect to remote work of journalists at newspapers the situation is somewhat less complex. Practically everyone worked from home. In both cases, the papers had editorial systems that journalists, photojournalists and layout people could connect to remotely and gain access to all the folders and files needed. Neither Guðmundur Hermannsson at Morgunblaðið nor Jón Pórisson at Fréttablaðið considered this a problematic part of the response to the ban. But it meant that for a long time there were only one or maybe two people physically located in the newsrooms. Here too, as with the broadcast media, reports for the website were mostly done from home. 


\section{Communication}

Communication is a vital element in editorial work, not least during editorial meetings and the flow of information during the course of the day. Fréttablaðið used the communication platform Slack for communication between journalists, editors and layout, but all the other editorial offices used Microsoft Teams. Both platforms offer similar options for communication for example organisation into working groups. These features were used, and communication channels established in accordance with different tasks and teams. Most often working groups would be created ad hoc and depend on the issues on the agenda, but not always. At Morgunblaðið, for example, there were four permanent channels within Teams, one for communication with and between editors, another for communication on layout, the third one for general exchange of views between journalists and other staff and the fourth was for communication with and within the business supplement.

Editorial meetings remained central to the process but took place online and included both journalists at home and any journalists working from the newsroom. According to the editorial chiefs the new format did not spoil the usefulness of these meetings and although the format was in some ways not as fluid as in normal times, the meetings were in some cases even more to the point and more efficient than before. Morgunblaðið took a somewhat different approach than the other three firms as only a morning meeting of editors was maintained but not a general meeting with the journalists. Instead, different groups or departments communicated internally.

It seems that communication between journalists and between journalists and editors throughout the day did not always go as smoothly as hoped for, and both Jón Pórisson (Fréttablaðið) and Heiðar Örn Sigurfinnsson (RÚV) mentioned that this created occasional misunderstandings or problems. Generally, however, communication improved as people became more familiar with the technologies and processes involved and had become quite effective towards the end of the period.

It is interesting to note a common tone of surprise and triumph from the editorial chiefs, regarding the speed with which journalists and indeed the entire editorial staff adopted new platforms and adjusted to a whole new system of communication.

\section{Workflow and deadlines}

Work processes and workflow with internal deadlines are important in the newsroom. Maintaining these did not, in the view of the editorial chiefs, present any significant difficulties in any the four newsrooms. At Fréttablaðið there were minor delays, particularly in the beginning, which caused the paper once or twice to stretch its deadline for going to print. This was however not of any significant consequence. Similarly, at RÚV television the news deadline was moved forward 30 minutes, in order to create a buffer time in case anything went wrong. Thus, it seems that radically different practices did not seriously upset internal workflows and deadlines in any of the four media companies examined. 


\section{STJÓRNSÝSLA}

\section{Social interaction/isolation}

Although working from home and the relative isolation this entailed did not affect workflow and communication was in most cases adequate, the editorial chiefs agreed that there was a social dimension missing. There was a lack of informal exchanges and synergy that is created by the very process of newsgathering, which can be hard to come by alone at home, and complicated by other needs such as attending to children and domestic duties in between journalistic work. This element was apparent in the exchange with the chiefs and is captured well in the following elaboration by Pórir Guðmundsson:

It became apparent how important the newsroom at Suðurlandsbraut (street name) is for our operation. Frequent and timely interactions about big and small issues play an important part in the development of a news story from an idea and into words, to a screen or radio. Sometimes the newsroom becomes like a living organism that breaths and moves in a steady beat and sometimes things just seem a chaos. Such things rarely happen on Teams.

\subsection{Experience of journalists}

Before looking at the results of the survey among active journalists it is useful to establish the proportion of journalists that actually had to change their work practices and how. As can be seen in Figure 1 a little more than one third of the respondents worked exclusively at home while $45 \%$ worked partly at home and about 3\% did not in any case normally work at the office. This means that it can be expected that $82 \%$ of active journalist were working partly or entirely at home during the ban on gatherings.

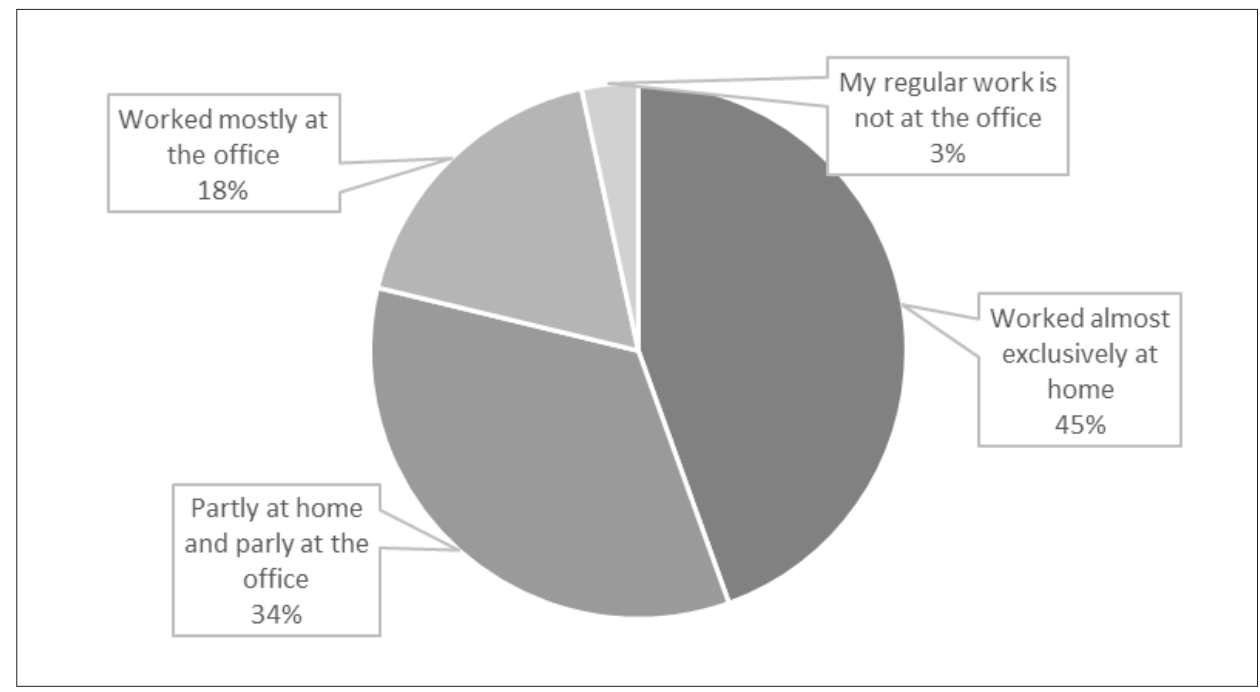

Figure 1. The proportion of journalists who said they were working altogether, partly or not at all at home during the ban on gatherings 
Addressing the second research question, the question of journalists' experience of different working practices during the ban, journalists were asked about their experience of remote work arrangements. As can be seen in Table 1 only a small minority describe their experience of remote work as being rather difficult or as an impossible working arrangement. On the other hand, just over $40 \%$ of journalists describe their experience in such a way that this arrangement can be good for some periods of time, while equally many are very happy with this arrangement. Thus, a vast majority of $82 \%$ is satisfied with remote working for some of the time at least.

Table 1. What of the following best describes your experience of working from home

\begin{tabular}{lcccccc}
\hline & Impossible & Rather difficult & Okay for a while & Very good & No opinion & N \\
\hline Everyone & $1 \%$ & $5 \%$ & $41 \%$ & $41 \%$ & $9 \%$ & 148 \\
\hline Men & $2 \%$ & $3 \%$ & $51 \%$ & $37 \%$ & $7 \%$ & 92 \\
\hline Women & $0 \%$ & $9 \%$ & $25 \%$ & $49 \%$ & $15 \%$ & 55 \\
\hline Print & $0 \%$ & $3 \%$ & $47 \%$ & $47 \%$ & $3 \%$ & 32 \\
\hline Website & $0 \%$ & $9 \%$ & $52 \%$ & $39 \%$ & $0 \%$ & 23 \\
\hline Broadcasting & $0 \%$ & $12 \%$ & $48 \%$ & $20 \%$ & $16 \%$ & 25 \\
\hline Print \& web & $5 \%$ & $2 \%$ & $27 \%$ & $66 \%$ & $0 \%$ & 41 \\
\hline Broadcast \& web & $0 \%$ & $4 \%$ & $42 \%$ & $19 \%$ & $36 \%$ & 26 \\
\hline
\end{tabular}

Note: The table shows the responses to the question of experience of working at home during the ban on gatherings. Answers are shown for all respondents and divided by gender and type of media outlet that the journalists are primarily working for.

As demonstrated in Table 1 there are some gender differences in the experiences of working from home. Women are considerably more positive towards this type of work (and also a little more negative) than men as almost every other woman journalist is happy with the arrangement as opposed to $37 \%$ of men, who are keener than women on remote work for limited periods of time. Indeed, a chi - square test shows a significant association between gender and the experience of working from home (Cramer's $\mathrm{V}: 284 ; \mathrm{p}=.018)$.

Another interesting finding is that journalists who work in print or for print and web and to a little lesser extent web journalists, are more positive towards working from home than broadcast journalists. This does not come as a surprise as the nature of broadcasting, especially tv, often requires a special setting and the physical presence of the journalist than is the case for other forms of journalism.

Clearly, an important element affecting journalists experience is the condition of the equipment, software, and technology they used. When asked about this only $10 \%$ of journalists were dissatisfied with this. On the other hand, some $67 \%$ were rather or very satisfied with the equipment they had but $23 \%$ said the tools were neither satisfactory nor unsatisfactory. Having adequate tools can be seen as a prerequisite for a positive experience of remote working, which is borne out in a statistically significant correlation 


\section{STJÓRNSÝSLA}

between the perception of the state of equipment and the experience of working from home (Pearson correlation: .593; $\mathrm{P}=.00$ ).

Journalists were also asked if they felt a change in their editorial independence when working from home and if they found it more or less difficult to find sources and angles to frame their stories when working from home. On both these questions clear results emerge. A majority, 60\% thought that there was not much difference in finding sources and angles for stories and only 5\% found it easier while 35\% thought it to be more difficult. The response to the question on editorial independence was quite conclusive, as $81.6 \%$ said there was no change in editorial independence, $15.6 \%$ found that their independence had increased while only $2.8 \%$ found that it had diminished.

Finally, the question arises as to what views journalists have on whether working from home could replace traditional work practices.

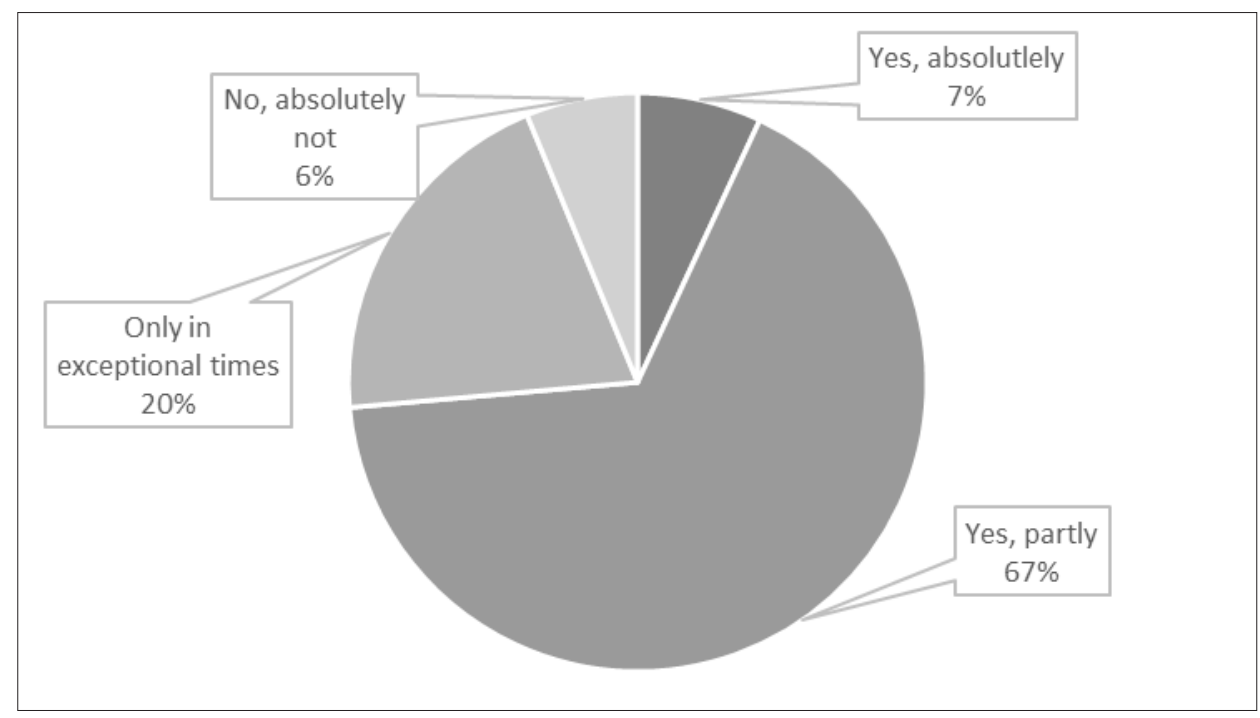

Figure 2. Proportion of respondents that feel remote work can replace fully, partly or not at all traditional work practices

As demonstrated in Figure 2 two roughly equal size minority groups oppose and celebrate the idea of replacing traditional work methods with remote work. The vast majority however feel that remote work can partly replace traditional practices, and a further $20 \%$ feels it can do so only in exceptional times. Clearly, the experience of the change during the ban on gatherings shapes and correlates with the views of journalists on replacing traditional practices with working from home (Pearson correlation .593; $\mathrm{P}=.00$ ). Other factors, that played a role in shaping the experience of journalist's, include the technical equipment and the type of platforms the journalist works primarily for. 


\subsection{The output}

When the media production of the selected periods in 2019 and 2020 are compared one of the first things that comes to light is the shrinking volume of the newspapers and the length of the news broadcasts of the private media. This should not come as a surprise as the size of the newspapers is largely determined by the amount of advertising available. The pandemic caused an immediate economic drawback which was directly translated into the advertising sector.

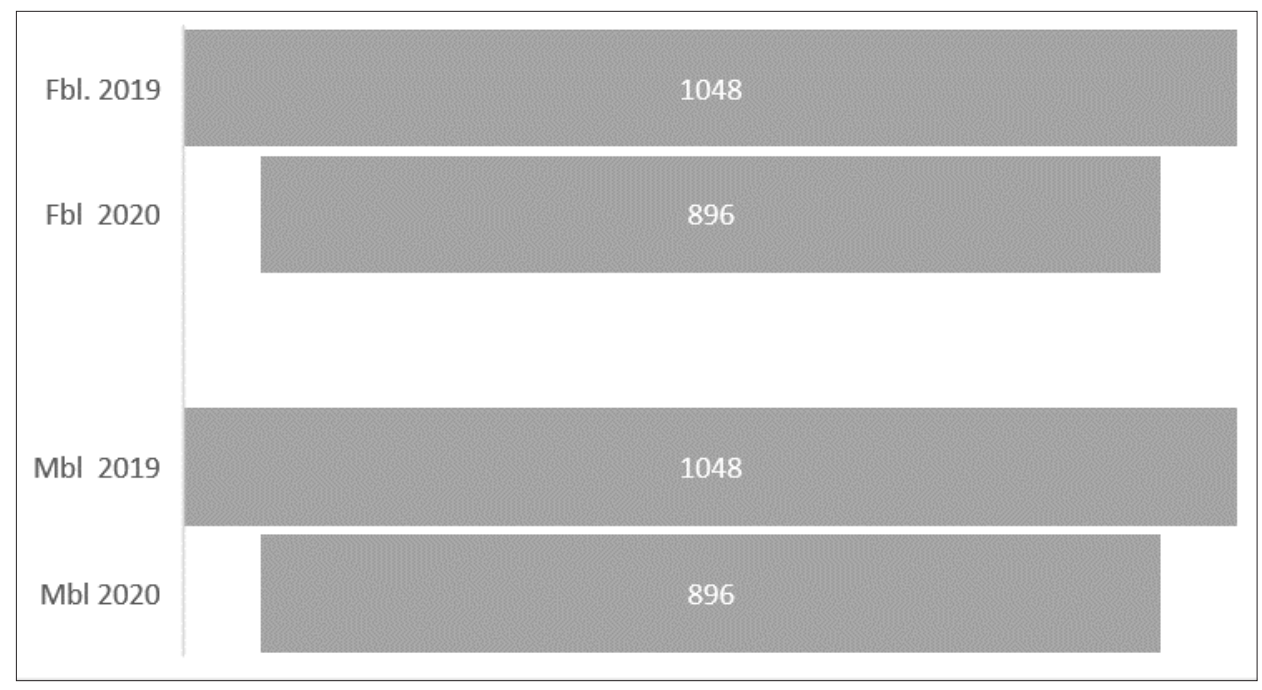

Figure 3. Total number of pages in newspapers during the examination period

Note: Fbl. $=$ Fréttablaðið and Mbl. $=$ Morgunblaðið.

This is illustrated in how during the examination period in 2020 Fréttablaðið had some 170 fewer ad pages than in the same period in 2019 and Morgunblaðið 72 fewer. But in spite of fewer pages - and the different nature of the two daily papers, one being a subscription paper while the other one is a free one - the change in the proportion of advertisements of the whole remained somewhat less dramatic as can be seen in Figure 4. 


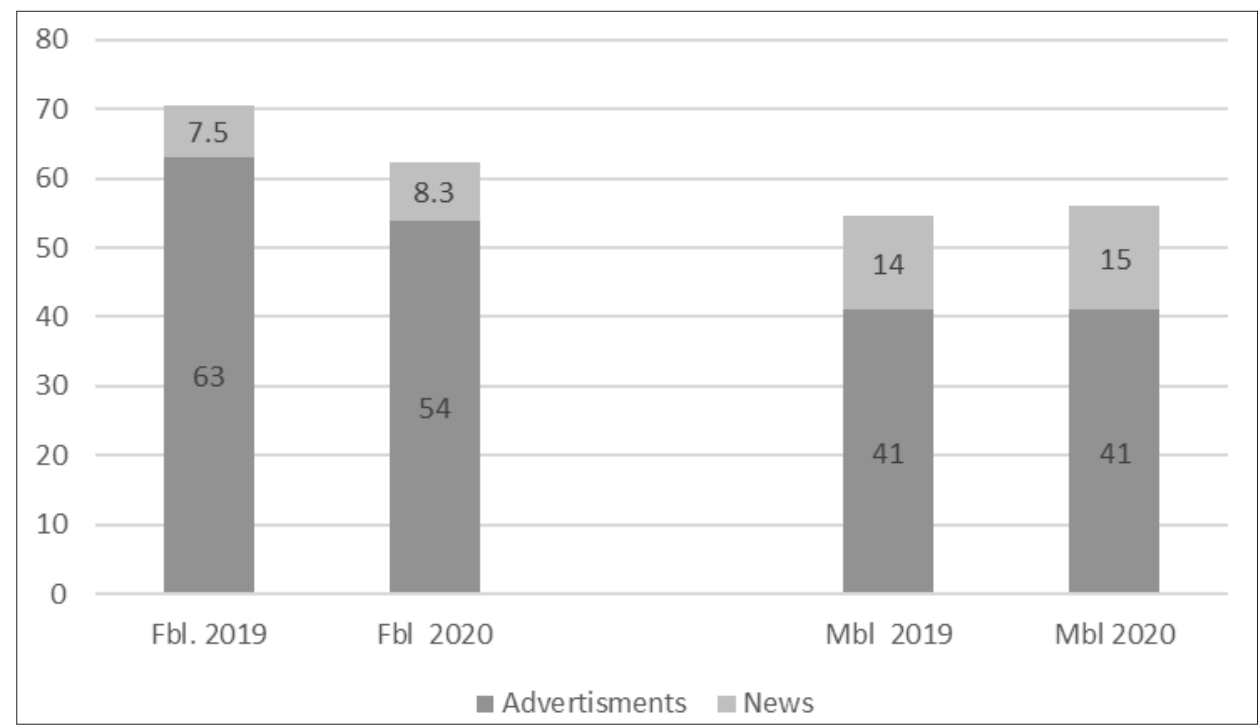

Figure 4. Proportion of advertisements on the one hand and news on the other in the two newspapers

Note: Fbl. $=$ Fréttablaðið and Mbl. $=$ Morgunblaðið.

Similar measurements cannot be produced for the broadcasting media, still an interesting tendency was detected when comparing the length, measured in minutes, of the total news broadcasting in the measuring period. There are fewer minutes broadcasted in 2020 in the private media while the opposite is true for RÚV, the public media (Figure 5).

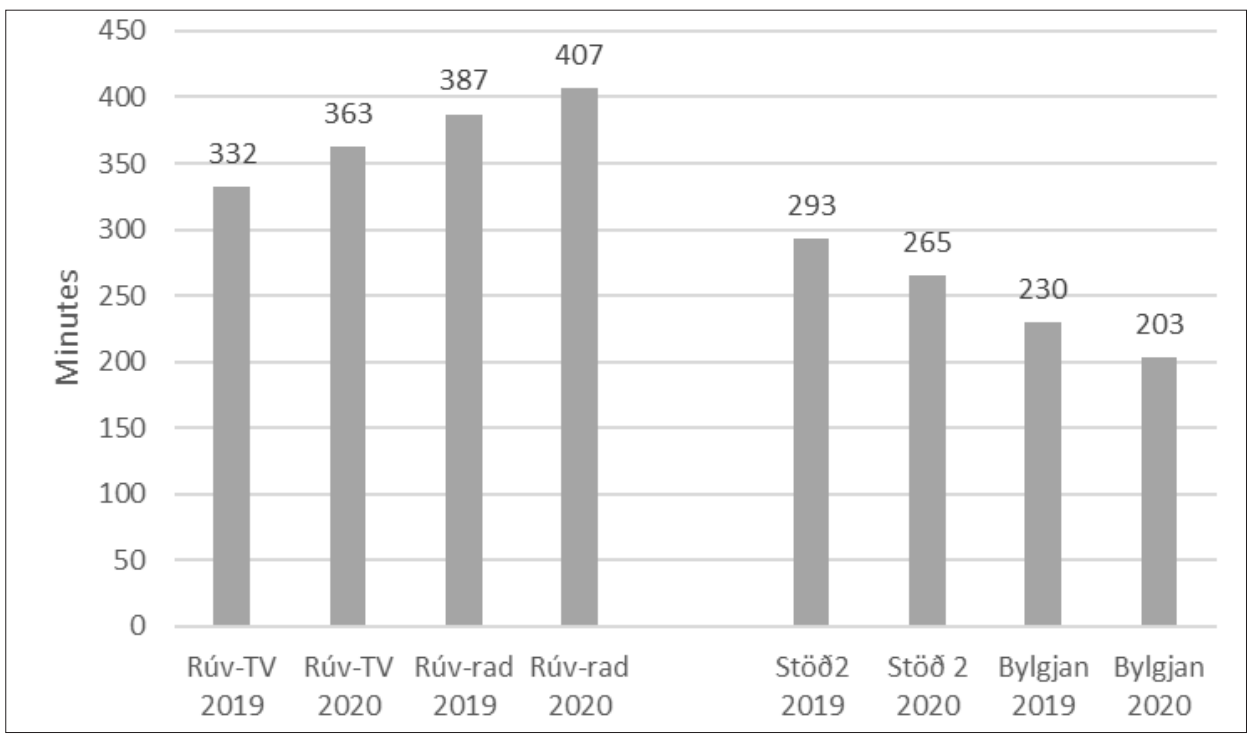

Figure 5. Total length in minutes of news broadcasting in the measuring period 
It is interesting to note the difference between private and public media in this respect and how consistently this difference appears in both radio and television.

The application of the five previously mentioned analytical categories help shed light on the nature and amount of work put into the news reporting, highlighting the differences that appear between print and broadcast and between private and public media.

As can be seen in Figure 6 considerable differences appear between years in both newspapers and although the numbers vary, the trend is similar in both cases. Two things are particularly noticeable, the increase in soft news during the ban on gatherings and the decrease at Morgunblaðið in news reports built on one or more independent sources.

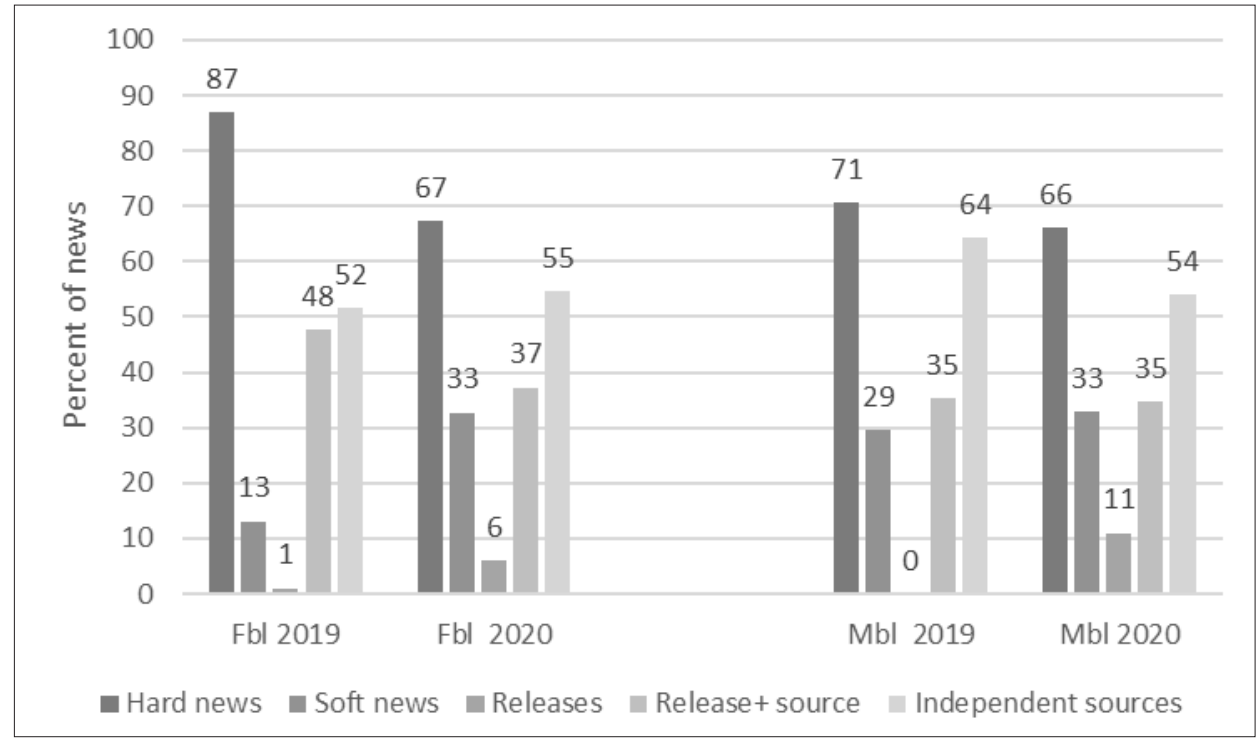

Figure 6. Comparison of the type of news content between years and the two daily papers

The increase of soft news is apparent in both papers, but much more so in Fréttablaðið, the free paper, that increased its soft news by 20 percentage points between 2019 and 2020. Fréttablaðið had a much lower ratio of soft news in 2019 but caught up with Morgunblaðið, which showed only a modest increase of 4 percentage points. Both papers have a similar ratio between soft and hard news in 2020. It should be reiterated that this refers only to those parts of the papers that report news and do e.g. not include lifestyle sections or special weekend supplements.

The decrease at Morgunblaðið in types of reports that are based on one or more independent sources is quite dramatic. This type of reports drops from just over twothirds of all reports in 2019 to just over one-half in 2020. A similar drop does however not happen at Fréttablaðið which keeps a little more than one half of all stories falling into this category of stories with one or more independent sources or $52 \%$ in 2019 and $55 \%$ in 2020 . This would indicate that the pandemic conditions had more impact on the 


\section{STJÓRNSÝSLA}

subscription paper than the free paper. This is further suggested by the category of raw press releases used, as the ratio for that category which displays increases from $1 \%$ to $6 \%$ at Fréttablaðið, but no less than an increase from $0 \%$ up to $11 \%$ at Morgunblaðið. In this context it is important to note that part of the explanation might lie in the different nature of these papers, i.e. subscription on the one hand and free on the other. The amount of news items in the subscription paper in the measured period was more than twice the number of items in the free paper in 2020. Other things being equal, changes in work processes can be expected to have greater impact on a larger production than a smaller one.

As a last point regarding the papers, there is a decrease in the reporting of Fréttablaðið in the category of news released with an identified source. Instead, there is an increase in the adjacent categories, "raw news releases" which require little journalistic work and "stories with one or more independent sources" that require much journalistic work. In other words, there is less time spent on stories where intermediate work is required (release + identified source), but more time is put into stories that require more work. Consequently, there is also a higher number of stories that require less work i.e. raw releases. One possible explanation is that this indicates a tendency to prioritize news stories in remote work were the journalists are allocated some cases early in the day which they follow diligently from home, leading to a higher number of work-intensive stories, fewer semi work-intensive and hence because of shortage of time, more stories that need to be covered with little work (raw releases).

Indeed, although the numbers do not highlight it, similar things may have been occurring at Morgunblaðið, i.e. increased prioritization of stories. Less time devoted to "less important issues" which are dealt with in raw releases, and more effort is put into maintaining the number of news reports that fall into the category of one or more independent sources.

When the data for the broadcasting platforms are examined (Figure 7), the high proportion of stories that fall into the category of independent sources becomes apparent. These work-intensive stories amount to some $70 \%$ and up to $94 \%$ of all stories. In this respect it is necessary to bear in mind the difference between print and broadcast. A news hour on radio or television carries much fewer news items than does a newspaper, besides the broadcast format calls to a higher degree for interviews with sources than does print. 


\section{STJÓRNSÝSLA}

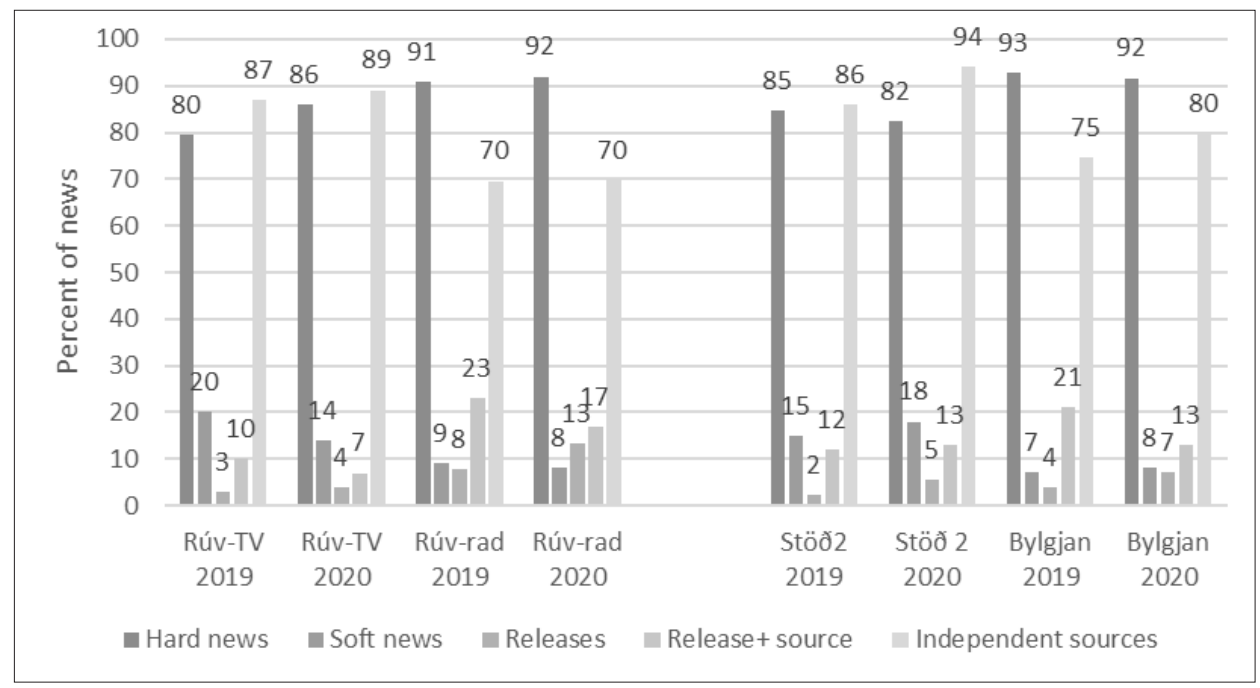

Figure 7. Comparison between the broadcast media, proportion of each category of the total measuring period measured in minutes

The data demonstrates that apart from a noticeable rise in hard news at Stöð 2, there really is not a significant difference in the five categories between the two years. Still, a similar prioritising tendency can be seen in broadcast media, particularly in radio, as was seen at Fréttablaðið, in terms of a decrease in medium work-intensive stories based on a release and an identified source. At RÚV radio this decrease constitutes five percent of all stories sand eight percentage points at Bylgjan, while at the same time there is an increase (or a standstill) in the other categories of stories.

\section{Discussion}

As discussed in the chapter on newsroom innovation an important body of scholarly literature has suggested that journalists in general have had a conservative mindset when it comes to change. Furthermore, this static syndrome has been seen as a problem when the whole media environment is extremely dynamic and is undergoing transformative change in a relatively short period of time. More actors than journalists are becoming instrumental in news reporting and traditional work practices and institutions of journalism such as the newsroom are being challenged. This has in turn highlighted the critical importance of professional journalism in a democratic society as disinformation and information overload can easily distort the attention of the public. Simultaneously, the economic foundations of traditional media are crumbling with advertising revenues and subscriptions diminishing. The Covid 19 pandemic has also made bad things worse pressing for change and innovation, that is not necessarily grounded in any concerns for journalism or democracy. That is undoubtedly the message coming from America and other places as is reported by the Tow Center Newsroom Cutback Tracker and the 


\section{STJÓRNSÝSLA}

Washington Post. The impact of the pandemic in Iceland may not be felt as acutely as in the United States or Europe, although the Icelandic media sector is also facing severe difficulties. Important rationalisation and reorganisation of the media industry took place already after the 2008 financial crisis in Iceland and thus it is possible that layoffs and closures did not hit this small media system as hard this time as it otherwise would have done. Massive layoffs of journalists and media workers have at least not yet been announced in Iceland, and media owners have not explicitly used the pandemic as a reason for major downsizing of the workforce. That seems however to be the case in many European countries as a resolution of the Annual Meeting of the Federation of European Journalists in early November bears witness to. The resolution on the "EU recovery Plan of the Media Sector" calls for the European Commission to ensure quality journalism considering that "media owners are taking advantage of the coronavirus crisis to reduce the number of journalists and multiply precarious jobs" (European Federation of Journalists 2020).

Whether or not remote work practices and newsroom downsizings or closures will become the norm in the future remains to be seen. However, the possibility and attempts in that direction most certainly will continue to be discussed as a possible new way of conducting journalism.

The results from the present study contributes this discussion in at least three ways. Firstly, the relatively successful practical response of newsrooms to the ban on gatherings in Iceland highlights the importance of preparation in organisation and the use of good equipment and software. Not only is it important to keep communication lines open and fluid, but in the long run social interaction must also be secured. The importance of "real" social interaction is apparent in this study of the first wave of the pandemic in Iceland. The continuation of the pandemic into a second and third wave has further highlighted this point as protests mount against social restrictions both in Iceland and in other countries. Pandemic fatigue thus underlines the potential draw backs of home working, but can also exaggerate these draw backs as homework or remote work becomes associated with the negative elements of a gathering ban, elements that prohibit social interaction that would be allowed in normal times. This could be considered an important experience for media firm administrators to consider in discussing possible changes in editorial offices.

Secondly, the "yes, but" syndrome does not seem to be a major obstacle for change, not in the context of a newsroom pandemic mode in Iceland. On the contrary journalists seemed quick to adapt to new work practices and simply adapt these new practices to more traditional journalistic values. Indeed, the vast majority of journalists feel remote work could partly or completely, replace older working practices. Even if it were considered to by a "yes, but" moment that such a large portion of the respondents only wants to partially replace traditional practises with new ones, the move is nevertheless an important change.

Finally, the output of media platforms during the ban on gatherings demonstrates that all examined outlets produced serious journalism. The comparison between years 
showed in most cases marginal differences although there are signs that suggest that slightly different emphasis might emerge in the type and nature of the news. Prioritizing of news stories and the time and work spent on them as well as an increase in soft news are examples.

Thus, lessons from the pandemic mode of newsrooms in Iceland are important for the discussion of future ways of conducting journalism, but further research is necessary to substantiate and deepen such contemplation.

\section{References}

Björnsson, I.P. (2019). "Verulegt tap hjá fjölmiðlum á síðasta ári”, RÚV, fréttir. Viewed 15 November 2020 at https://www.ruv.is/frett/verulegt-tap-hja-fjolmidlum-a-sidasta-ari

Blaðamaðurinn (2007). "Félagatal", (Organ of the Journalist Union of Iceland.) Viewed 17 November 2020 at https://www.press.is/static/files/bladamadurinn/bladamadurinn_mars-07.pdf

Blaðamaðurinn (2012). "Félagatal", (Organ of the Journalist Union of Iceland.) Viewed 17 November 2020 at https://www.press.is/static/files/bladamadurinn/bladamadur_des_12.pdf

Blaðamaðurinn (2012). "Félagatal", (Organ of the Journalist Union of Iceland.) Viewed 17 November 2020 at https://www.press.is/static/files/bladamadurinn/bladamadurinn-april-2020_-loka.pdf

Boczkowski, P.J. (2004) "The Processes of Adopting Multimedia and Interactivity in Three Online Newsrooms", Journal of Communication 54(2), 197-213.

Boczkowski, P.J. (2015). "The material turn in the study of journalism: Some hopeful and cautionary remarks from an early explorer", Journalism 16(1), 65-8.

Bryman, A. (2012). Social Research Methods (4 ${ }^{\text {th }}$ ed.). New York: Oxford University Press.

Bunce, M., Wright, K., and Scott, M. (2018) "Our newsroom in the cloud: Slack, virtual newsrooms and journalistic practice”, New Media and Society 20(9),3381-3399.

Chadwick, A. (2013). The Hybrid Media System. Politics and Power. New York: Oxford University Press.

European federation of Journalists (2020). Resolutions adopted by AM 2020. Viewed 19 November 2020 at https://europeanjournalists.org/wp-content/uploads/2020/11/EN-Resolutions-2020-AM-1.pdf

Guðmundsson, B. (2011). “Íslensk dagblöð fyrir og eftir hrun”, Rannsóknir i félagsvísindum XII: félags- og mannvisindadeild. Paper delivered in October at Djóðarspegillinn.

Guðmundsson, B. (2012). "Umræðuvettvangur íslenskra dagblaða með hliðsjón af greiningarramma Colin Sparks", The Icelandic Review of Politics \& Administration 8(2) 323-342.

Guðmundsson, B. (2018). "Media in a Microstate", in G. Baruchello, J.Th. Kristjánsson, K.M. Jóhannesdóttir, and S. Ingimarsson (eds.), No one is an Island. An Icelandic Perspective. Newcastle: Cambridge Scholars Publishing.

Guðmundsson, B. (2019). "Logics of the Icelandic Hybrid Media System. Snapchat and media-use before the 2016 and 2017 Althing elections", Nordicom Review 40(1), 43-60.

Guðmundsson B., and Kristinsson, S. (2017). "Journalistic Professionalism in Iceland: A Framework for Analysis and an Assessment", Journalism 20(12), 1684-1703.

Izadi, E. (2020). “The newsroom was the beating heart of a local newspaper. What's lost when the owner shuts it down?", Washington Post, August 18th. Viewed 17 August 2020 at https://www.washingtonpost.com/lifestyle/media/the-newsroom-was-the-beating-heart-of-a-local-newspaper-whats-lostwhen-the-owner-shuts-it-down/2020/08/17/6e9840e4-dcd8-11ea-8051-d5f887d73381_story.html

Jóhannsdóttir, V. (2016). "Markaðsvæðing frétta: Greining á innihaldi frétta í tveimur dagblöðum og tveimur vefmiðlum fyrir og eftir hrun", The Icelandic Review of Politics \& Administration 12(2), 303-320.

Jóhannsdóttir, V. (2018). "Commercialization in the Icelandic Press: An analysis of hard and soft news in major print and online media in Iceland in times of change", Journalism 21(11), 1762-1778. doi:10.1177/1464884918768494 


\section{STJÓRNSÝSLA}

Jóhannsdóttir, V., and Ólafsson, J.G. (2018) “The Icelandic news media in times of crisis and change", The Icelandic Review of Politics \& Administration. Special issue on power and democracy in Iceland 14(1), 189-210

Klinger, U., and Svenson, J. (2014). "The emergence of network media logic in political communication: A theoretical approach", New Media \& Society 12(1), 143-160.

Konow-Lund, M. (2020). "Reconstructing investigative journalism at emerging organisations", The Journal of Media Innovations. Special issue: Media Innovation and Social Change 6(1), 9-22.

Lanosga, G., Martin, J., and Camaj, L. (2019, September). Global Initiatives in Data Journalism in the Age of Big Data: Challenges and Opportunities. A Collection of Research Papers Submitted for the Global Investigative Journalism Conference September 2019, Hamburg, Germany. Investigative Journalism Education Consortium: Academic Track Reader.

Matthews, B., and Ross, L. (2010). Research methods. A practical guide for the social sciences. Longman: Pearson Education Ltd.

Media Pluralism Monitor (2020). Media Pluralism Monitor 2020: Upgraded Media Pluralism Monitor confirms risks to media pluralism across the EU. Published by the European Commission. Viewed 19 November 2020 at https://ec.europa.eu/digital-single-market/en/news/media-pluralism-monitor-2020-upgraded-media-pluralism-monitor-confirms-risks-media-pluralism

Nygren, G. (2019). "Local Media Ecologies", Nordicom Review 40(2), 51 -68.

Paulussen, S. (2016). "Innovation in the Newsroom", in T. Witschge, C.W. Anderson, D. Domingo, and A. Hermida (eds), The Sage Handbook of Digital Journalism. London, Sage Publications Ltd.

Ryfe, D.M. (2012). Can Journalism Survive? An Inside Look at American Newsrooms. Cambridge, England: Polity.

Tow Center (2020). The Tow Center COVID-19 Newsroom Cutback Tracker. Viewed 9 November at https:// www.cjr.org/widescreen/covid-cutback-tracker.php

White, A. (2008). To tell you the truth. The etbical journalism initiative. Brussels: International Federation of Journalists. International Press Centre.

Örnebring, H. (2009). "The two professionalisms of journalism: Journalism and the changing context of work", Reuters Institute for the Study of Journalism Working Paper, Oxford University. 